\title{
PENERAPAN METODE EKSPERIMEN UNTUK MENINGKATKAN PEMAHAMAN KONSEP SISWA KELAS IV SEKOLAH DASAR PADA PEMBELAJARAN IPA
}

\author{
Nurhayati ${ }^{1}$ \\ Mariah Ulfah ${ }^{2}$ \\ ${ }^{1}$ Guru SDN Wiru Kencana \\ 2Dosen STKIP Subang \\ ${ }^{2}$ mariahulfah1990@yahoo.com
}

\begin{abstract}
Application of Experimental Methods to Increase Understanding of the Concept of Grade IV Primary School Students in Science Lesson. The purpose of this study is to describe data on: (1) student activity in science learning by applying experimental method; (2) improvement of understanding of science concept by applying experiment method. The method used in this research is a classroom action research with Kemmis \& Mc design. Taggart. This research was conducted in the odd semester of academic year 2017/2018 at SD Negeri Wirukencana in grade 4 students. Data collection techniques used are observation, test and documentation. Based on the processing and data analysis, the results of this study are: (1) Student activity at the time of learning using experimental method that is in the first stage students pay attention to the initial experiments conducted by the teacher as evidenced by answering questions asked by teachers around the experiment. Then at the observation stage all the students recorded things that happened while observing the experiments performed by the teacher. The third stage of the students make a hypothesis according to the conceptual observation based on observation. Furthermore, in the verification stage students conduct experiments that refer to the LKS in a group way, the students divide each task on each member of the group such as the task as chairman of the group, secretary, moderator and other tasks in the experiment. After the students complete the experiment each group discuss or present the results of his group's observations in front of the class. The fifth stage is the application of concepts, the students are able to give examples of the alteration of changes in the form of things in everyday life; and (2) The application of experimental methods in general can increase the understanding of the concept of fourth grade students.
\end{abstract}

Keywords: Experiment Method, Concept Understanding

\section{ABSTRAK}

Penerapan Metode Eksperimen untuk Meningkatkan Pemahaman Konsep Siswa Kelas IV Sekolah Dasar pada Pembelajaran IPA. Tujuan penelitian ini yaitu untuk mendeskripsikan data mengenai: (1) Aktivitas siswa 
dalam pembelajaran IPA dengan menerapkan metode eksperimen; (2) peningkatan pemahaman konsep IPA dengan menerapkan metode eksperimen. Metode yang digunakan dalam penelitian ini adalah penelitian tindakan kelas dengan desain Kemmis $n$ Mc. Taggart. Penelitian ini dilaksanakan pada semester ganjil tahun pelajaran 2017/2018 di SD Negeri Wirukencana pada siswa kelas IV. Teknik pengumpulan data yang digunakan yaitu observasi, tes dan dokumentasi. Berdasarkan pengolahan dan analisis data, hasil penelitian ini yaitu: (1) Aktivitas siswa pada saat pembelajaran menggunakan metode eksperimen yaitu pada tahap pertama siswa memperhatikan percobaan awal yang di lakukan oleh guru yang dibuktikan dengan menjawab pertanyaan yang diajukan guru seputar percobaan. Kemudian di tahap pengamatan semua siswa mencatat hal-hal yang terjadi saat mengamati percobaan yang dilakukan guru. Tahap yang ke tiga siswa membuat hipotesis sesuai pemhaman konsepnya berdasarkan pengamatan. Selanjutnya di tahap verifikasi siswa melakukan percobaan yang mengacu pada LKS dengan cara berkelompok, siswa membagi tugas masing-masing pada setiap anggota kelompok seperti tugas sebagai ketua kelompok, sekretaris, moderator dan tugas lainnya dalam percobaan. Setelah siswa menyelesaikan percobaanya setiap kelompok berdiskusi atau mempresentasikan hasil pengamatan kelompoknya di depan kelas. Tahap yang kelima yaitu aplikasi konsep, siswa mampu memberikan contoh pemnafaatan perubahan wujud benda dalam kehidupan sehari-hari; dan (2) Penerapan metode eksperimen secara umum dapat meingkatkan pemahaman konsep siswa kelas IV .

Kata Kunci : Metode Eksperimen, Pemahaman Konsep

\section{A. PENDAHULUAN}

Pelajaran IPA disekolah dasar sangatlah penting oleh karena itu seorang guru perlu merencanakan strategi agar pelaksanaan pembelajaran IPA efektif dan efisien dan tujuan pembelajaran yang diharapkan dapat tercapai yaitu dengan menerapkan berbagai metode dan pendekatan pembelajaran. Pembelajaran IPA merupakan pembelajaran alam yang mempunyai hubungan sangat luas terkait dengan kehidupan manusia. Hal ini sejalan dengan tuntutan dari pembelajaran IPA Sekolah Dasar, yaitu: mengembangkan pengetahuan dan pemahaman konsep-konsep IPA yang bermanfaat dan dapat diterapkan dalam kehidupan sehari-hari, (2) mengembangkan keterampilan proses untuk menyelidiki alam sekitar, memecahkan masalah dan membuat keputusan. 
Nikson (Ratumanan 2002:3) mengemukakan

bahwa

"pembelajaran merupakan suatu upaya membantu siswa mengkonstruksi (membangun) konsep-konsep dan prinsip-prinsip ilmu pengetahuan dengan kemampuannya sendiri melalui internalisasi sehingga konsep dan prinsip itu terbangun kembali". Oleh karena itu, guru diharapkan menciptakan kondisi pembelajaran IPA yang memungkinkan siswa dapat belajar secara aktif, kreatif dan bermakna bagi siswa, salah satunya dengan memberikan pengalaman langsung kepada siswa dalam memahami prinsip dan konsep IPA, sehingga siswa sendiri yang membangun pengetahuan mengenai prinsip dan konsep IPA tersebut, melalui proses pengkonstruksian pemikiran mereka sendiri. Proses pembelajaran yang menekankan pada pemberian pengalaman langsung untuk mengembangkan kompetensi agar memahami alam sekitar secara ilmiah dapat memberikan kesan bermakna bagi siswa, karena siswa tidak merasa diberi tahu melainkan mencari tahu sendiri konsep dan prinsip IPA tersebut melalui kegiatan memanipulasi alat peraga, serta melalui proses pengkonstruksian pemikiran mereka sendiri dengan begitu siswa dapat lebih memahami konsep materi IPA.

Dari data observasi selama pembelajaran IPA mengenai materi perubahan wujud benda ditemukan bahwa selama pembelajaran berlangsung sebagian besar aktivitas siswa yaitu mendengarkan materi yang disampaikan oleh guru. Kesempatan siswa untuk terlibat langsung dalam proses penemuan konsep dengan memanipulasi alat peraga masih sedikit. Pemahaman siswa dari hasil pembelajaran tersebut yaitu masih rendah hal ini dapat diketahui dari nilai hasil Ulangan Harian mengenai pemahaman konsep IPA tentang perubahan wujud benda, dengan KKM sebesar 63 ternyata dari 11 siswa hanya $55 \%$ yang mampu mencapainya. Hal ini sangat jauh dari target yang diharapkan yaitu 
semua siswa mencapai nilai Kriteria Ketuntasan Minimal (KKM).

Oleh karena itu peneliti bermaksud mengatasi masalah tersebut dengan menerapkan metode pembelajaran yang sesuai dengan pembelajaran IPA di Sekolah Dasar. Salah satu metode yang sesuai dengan masalah yang terjadi yaitu metode eksperimen. Menurut Schoenher (Heriawan, dkk 2012: 86) mengemukakan bahwa "metode eksperimen merupakan metode yang sesuai untuk pembelajaran sains, karena metode eksperimen mampu memberikan kondisi belajar yang dapat mengembangkan kemampuan berpikir dan kreativitas secara optimal". Siswa diberi kesempatan untuk menyusun sendiri konsep-konsep dalam struktur kognitifnya, selanjutnya dapat diaplikasikan dalam kehidupannya.

Sumantri (Rafika, 2015: 11) mengemukakan bahwa "metode eksperimen adalah sebagai cara belajar mengajar yang melibatkan peserta didik dengan mengalami, menguji dan membuktikan sendiri proses dan hasil percobaan." Pembelajaran IPA dengan metode eksperimen memberikan siswa untuk bekerja dengan memanipulasi benda-benda, bahan-bahan, dan peralatan laboratorium, baik secara perorangan maupun kelompok. Eksperimen merupakan situasi pemecahan masalah yang di dalamnya berlangsung pengujian suatu hipotesis, dan variabelvariabel yang dikontrol secara ketat. Hal yang diteliti dalam suatu eksperimen adalah pengaruh variabel tertentu terhadap variabel lain.

Terdapat

beberapa karakteristik mengajar dalam menggunakan metode ekperimen serta hubungannya dengan pengalaman belajar siswa, seperti yang dikemukakan oleh Rafika (2014: 15), yaitu:

1. Metode untuk membelajarkan siswa dengan melakukan percobaan, pengamatan dan penarikan kesimpulan terhadap sesuatu yang sedang diuji kebenarannya. 
2. Metode yang dirancang untuk mengembangkan pengetahuan siswa dalam mengembangkan pengetahuan siswa dalam pembelajaran tertentu

3. Metode yang membantu siswa dalam pemerosesan informasi yang aktif, sehingga membantu mereka dalam belajar akan menyesuaikan diri dengan lingkungannya

4. Metode yang mengarahkan siswa mempelajari lingkungan belajar sebagai suatu ekologi

5. Metode yang digunakan untuk memecahkan masalah yang bersifat ilmiah.

Dari karakterisitik tentang metode eksperimen dapat ditarik kesimpulan bahwa metode eksperimen dapat dikembangkan dan diterapkan dalam pembelajaran IPA dalam meningkatkan sikap ilmiah siswa, sikap ilmiah dapat muncul dalam pembelajaran melalui pengalaman melakukan eksperimen.

Jika siswa akan melaksanakan suatu eksperimen perlu memperhatikan prosedurnya. Berikut prosedur metode eksperimen menurut Roestiyah (2012: 81):

1. Perlu dijelaskan kepada siswa tentang tujuan eksperimen, mereka harus memahami masalah yang akan dibuktikan melalui eksperimen.

2. Kepada siswa perlu diterangkan pula tentang:

a. Alat-alat serta bahan-bahan yang akan digunakan dalam percobaan.

b. Agar tidak mengalami kegagalan siswa perlu mengetahui variabel-variabel yang harus dikontrol dengan ketat.

c. Urutan yang akan ditempuh sewaktu eksperimen berlangsung.

d. Seluruh proses atau hal-hal yang penting saja yang akan dicatat.

e. Perlu menetapkan bentuk catatan atau laporan berupa uraian, perhitungan, grafik, dan sebagainya.

3. Selama eksperimen berlangsung, guru harus mengawasi pekerjaan siswa, bila perlu member saran atau 
pertanyaan yang menunjang kesempurnaan jalannya eksperimen.

4. Setelah eksperimen selesai guru harus mengumpulkan hasil penelitian siswa, mendiskusikan ke kelas, dan mengevaluasi dengan tes atau sekedar Tanya jawab.

Agar penggunaan metode eksperimen itu efisien dan efektif, menurut Heriawan, dkk (2012: 87) maka perlu diperhatikan hal-hal sebagai berikut:

1. Dalam eksperimen setiap siswa harus mengadakan percobaan, maka jumlah alat dan bahan atau materi percobaan harus cukup bagi tiap siswa.

2. Agar eksperimen itu tidak gagal dan siswa menemukan bukti yang meyakinkan, atau mungkin hasilnya tidak membahayakan, maka kondisi alat dan mutu percobaan yang digunakan harus baik dan bersih.

3. Dalam eksperimen siswa perlu teliti dan konsentrasi dalam mengamati proses percobaan, maka perlu adanya waktu yang cukup lama, sehingga mereka menemukan pembuktian kebenaran dari teori yang dipelajari itu.

4. Siswa dalam eksperimen adalah sedang belajar dan berlatih, maka perlu di beri petunjuk yang jelas, sebab mereka disamping memperoleh pengetahuan, pengalaman serta keterampilan, juga kematangan jiwa dan sikap perlu diperhitungkan oleh guru dalam memilih objek eksperimen itu.

5. Tidak semua masalah bisa dieksperimenkan, seperti masalah mengenai kejiwaan, beberapa segi kehidupan social dan keyakinan manusia.

Langkah-langkah metode pembelajaran dengan metode eksperimen menurut Palendeng (Heriawan, dkk, 2012: 87) adalah sebagai berikut:

1. Percobaan awal, pembelajaran diawali dengan melakukan percobaan yang didemonstrasikan guru atau 
dengan mengamati fenomena alam. Demonstrasi ini menampilkan masalahmasalah yang berkaitan dengan materi fisika yang akan dipelajarai.

2. Pengamatan, merupakan kegiatan siswa saat guru melakukan percobaan. Siswa diharapkan untuk mengamati dan mencatat peristiwa tersebut.

3. Hipotesis awal, siswa dapat merumuskan hipotesis sementara berdasarkan hasil pengamatannya.

4. Verifikasi, kegiatan untuk membuktikan kebenaran dari dugaan awal yang telah dirumuskan dan dilakukan melalui kerja kelompok. Siswa di harapkan merumuskan hasil percobaan dan membuat kesimpulan, selanjutnya dapat dilaporkan hasilnya.

5. Aplikasi konsep, setelah siswa merumuskan dan menemukan konsep, hasilnya di aplikasikan dalam kehidupannya. Kegiatan ini merupakan pemantapan konsep yang telah dipelajari.
6. Evaluasi, merupakan kegiatan akhir setelah selesai satu konsep.

Berdasarkan pemaparan di atas, dengan menerapkan metode ekspierimen dalam pembelajaran IPA dapat membantu siswa dalam memahami konsep IPA. Dalam pembelajaran dengan metode eksperimen siswa distimulus untuk mengaitkan konsep yang sedang dipelajarinya tersebut dengan kehidupan nyata, menemukan sendiri, bekerjasama, menerapkan dan mentransfer dalam konteks baru.

Menurut Ausubel (Dahar, 2011: 64) konsep diperoleh dengan dua cara, yaitu pembentukan konsep dan aslimilasi konsep. Pembentukan konsep terutama merupakan bentuk perolehan konsep sebelum anak-anak masuk sekolah. Pembentukan konsep dapat disamakan dengan belajar konsep konkret menurut Gagne (Dahar, 2011: 64) "asimilasi konsep merupakan cara utama untuk memperoleh konsep selama dan sesudah sekolah". Dahar $(2011,64)$ berpendapat bahwa: 
Pembentukan

konsep

merupakan proses induktif. Bila

anak di hadapkan pada stimulus lingkungan, ia mengabstraksi sifat atau atribut tertentu yang sama dari berbagai stimulus. Pembentukan konsep merupakan suatu bentuk belajar penemuan, paling sedikit dalam bentuk primitive. Pembentukan konsep juga ditunjukan oleh orang-rang yang lebih tua dalam situasi kehidupan nyata dan laboratorium, tetapi dengan tingkat kerumitan yang lebih tinggi.

Pemahaman diekspresikan dalam bentuk kemampuan memahami informasi, memanfaatkan dan mengekstrapolasi pengetahuan dalam konteks baru, menjelaskan makna, menginterpretasi fakta, memprediksi dan mengekstrapolasi pengetahuan tersebut untuk dimanfaatkan dalam situasi lain. Hasil belajar berupa pemahaman dapat dibedakan menjadi tiga kategori yakni pemahaman terjemahan (menerjemahkan bahasa atau istilah); pemahaman penafsiran (menghubungkan bagian-bagian dari suatu kejaaadian, membedakan yang pokok dengan yang bukan pokok); pemahaman ekstrapolasi (kemampuan melihat makna yang tersirat, dapat membuat asumsi tentang konsekuensi dari suatu kejadian). Meskipun pemahaman terbagi menjadi tiga tingkatan namun sulit menarik garis batas yang tegas antara jenis yang satu dengan yang lainnya. Kata kerja operasional yang digunakan untuk merumuskan tujuan pembelajaran pada kategori ini antara lain: mengubah, mengkonversi, mengelompokan, mendeskripsi, menjelaskan, merangkum, menggeneralisasi,

menerjemahkan, memprediksi (Jufri, 2013: 61).

Dari penjelasan di atas dapat ditarik kesimpulan bahwa pemahaman konsep yaitu kemampuan seseorang dalam mengartikan, menafsirkan, menerjemahkan atau menyatakan sesuatu dengan caranya sendiri tentang pengetahuan yang pernah 
di pelajari atau diterimanya. Kemampuan ini umumnya mendapat penekanan dalam proses belajar mengajar.

Menurut Anderson (2015: 100101) indikator pemahaman konsep sebagai berikut:

1. Menafsirkan

Menafsirkan terjadi ketika siswa dapat mengubah informasi dari satu bentuk ke bentuk lain. Menafsirkan berupa pengubahan kata-kata lain (misalnya, memparafrasakan), gambar dari kata-kata, kata-kata jadi gambar, angka jadi kata-kata, kata-kata jadi angka, not balok jadi suara music, dan semacamnya. Nama-nama lainnya adalah menerjemahkan, memparafrasakan,

menggambarkan, dan mengklarifikasi.

2. Mencontohkan

Proses kognitif mencontohkan terjadi manakala siswa memberikan contoh tentang konsep atau perinsip umum.. mencontohkan melibatkan proses indentifikasi cirri-ciri pokok dari konsep atau prinsip umum (misalnya, segitiga sama kaki harus mempunyai dua sisi yang sama panjang) dan menggunakan cirri-ciri untuk memilih atau membuat contoh (misalnya, siswa dapat memilih segitiga sama kaki dari segitiga yang ditunjukan). Nama-nama lain untuk mencontohkan adalah mengilustrasikan dan member contoh.

3. Mengklasifikasikan

Proses

kognitif mengklasifikasikan terjadi ketika sisswa mengetahui bahwa sesuatu (misalnya, suatu contoh) termasuk dalam kategori tertentu (misalnya, konsep atau prinsip). Mmengklasifikasikan adalah proses kognitif yang melengkapi proses mencontohkan. Jika mencontohkan dimulai dengan konsep atau prinsip umum dan mengharuskan siswa menemukan contoh tertentu, mengklasifikasikan dimulai dengan contoh tertentu dan mengharuskan siswa menemukan konsep atau prinsip umum. Nama-nama lain dari mengklasifikasikan adalah mengategorikan dan mengelompokan. 
4. Merangkum

Proses kognitif merangkum terjadi ketika siswa mengemukakan satu kalimat yang merepresentasikan informasi yang diterima atau mengabstraksikan sebuah tema. Merangkum melibatkan proses membuat ringkasan informasi, misalnya makna suatu adegan drama, dan proses mengabstraksikan ringkasannya, misalnya menentukkan tema atau poin-poin pokoknya. Nama-nama lain untuk merangkum adalah menggeneralisi dan mengabstraksi.

5. Menyimpulkan

Proses kognitif menyimpulkan menyertakan proses menemukan pola dalam sejumlah contoh. Menyimpulkan terjadi ketika siswa dapat mengabstraksikan sebuah konsep atau prinsip yang menerangkan contoh-contoh tersebut dengan mencermati cirriciri setiap contohnya dan, yang terpenting, dengan menarik hubungan diantara cirri-ciri tersebut. Misalnya, ketika siswa diberi angka-angka 1, 2, 3, 5, 8, 13, 21, mereka memperhatikan nilai numeric setiap digit, bukan cirri-cirinya yang tak relevan seperti bentuk setiap digit atau apakah setiap digitnya ganjil atau genap. Mereka dapat membedakan pola dalam susunan angka tersebut (yakni setelah dua angkka pertama, setiap angkanya merupakan jumlah dari dua angka sebelumnya).

6. Membandingkan

$$
\text { Proses }
$$

kognitif

membandingkan

melibatkan proses menditeksi persamaan dan perbedaan antara dua atau lebih objek, peristiwa, ide, masalah, atau situasi, seperti menentukan bagaimana suatu peristiwa terkenal (misalnya, skandal politik terbaru) menyerupai peristiwa yang kurang terkenal (misalnya, skandal politik terdahulu). Membandingkan meliputi pencairan korespondensi satu-satu antara elemen-elemen dan polapola pada satu objek, peristiwa, atau ide dan elemen-elemen dan pola-pola pada satu objek, peristiwa, atau ide lain. Jika digunakan bersama menyimpulkan (misalnya,

pertama, 
mengabstraksikan suatu kaidah dari situasi yang familier) dan menginplementasikan (misalnya, kedua, menerapkan kaidahb tersebut pada situasi yang kurang familier), membandingkan dapat mendukung penalaran dengan analogi. Nama-nama lainnya adalah mengontraskan, memetakan, mencocokan.

7. Menjelaskan

Proses kognitif menjelaskan berlangsung ketika siswa dapat membuat dan menggunakan model sebab-akibat dalam sebuah sistem. Model ini dapat diturunkan dari teori (sebagaimana sering terjadi dalam sains) atau di dasarkan pada hasil penelitian atau pengalaman (sebagaimana kerapkali terjadi dalam ilmu social dan humaniora). Penjelasan yang lengkap melibatkan proses membuat model sebab-akibat, yang mencakup setiap bagian pokok dari suatu sistem atau peristiwa penting dalam rangkaian peristiwa, dan proses menggunakan model ini untuk menentukan bagaimana perubahan pada satu bagian dalam sistem tadi atau sebuah "peristiwa" dalam rangkaian peristiwa tersebut mempengaruhi perubahan pada bagian lain. Nama lain dari menjelaskan adalah membuat model.

Tujuan penelitian ini yaitu untuk mendeskripsikan data mengenai: (1) Aktivitas siswa dalam pembelajaran IPA dengan menerapkan metode eksperimen; (2) peningkatan pemahaman konsep IPA dengan menerapkan metode eksperimen.

\section{B. METODE}

Penelitian tindakan kelas ini dilaksanakan di SD Negeri Wirukencana yang terletak di Desa Marengmang Kecamatan Kalijati Kabupaten Subang. Adapun yang menjadi subjek penelitian tindakan kelas ini terdiri dari 11 orang siswa yang duduk di kelas IV yang meliputi 6 orang siswa laki-laki dan 5 orang siswa perempuan.

Metode penelitian yang digunakan dalam penelitian ini adalah metode penelitian tindakan kelas (PTK). Desain penelitian yang digunakan yaitu desain yang 
dikembangkan oleh Kemmis dan Mc Taggart. Desain ini memiliki empat tahapan, yakni perencanaan tindakan, pelaksanaan tindakan, observasi dan tahap refleksi. Keempat tahapan tersebut dilakukan dalam satu rangkaian yang disebut siklus (Arikunto, 2013: 137).

Untuk memperoleh data pada penelitian ini yaitu dengan menggunakan teknik observasi, tes dan dokumentasi. Adapun instrumen penelitian yang digunakan dalam penelitian ini adalah sebagai berikut:

\section{Lembar Observasi}

Lembar observasi digunakan untuk mengamati, merekam segala peristiwa dan kegiatan yang terjadi selama proses pembelajaran berlangsung sebagai tindakan perbaikan atau peningkatan upaya pembelajaran ke arah lebih baik dalam pembelajaran IPA dengan menggunakan metode eksperimen.

\section{Tes}

Tes diberikan untuk mengukur atau mengetahui kemampuan pemahaman konsep siswa, baik sebelum maupun sesudah perlakuan diberikan. Tes tersebut berisikan tes kemampuan pemahaman konsep siswa berupa soal esai yang berkaitan dengan materi perubahan wujud benda. Jenis tes yang digunakan adalah tes tertulis.

\section{Kamera dan Perekam Video}

Kamera yang dimaksud dalam penelitian ini adalah alat untuk mengambil suatu gambar atau foto-foto dalam proses pembelajaran berlangsung. Sedangkan perekam video alat yang digunakan untuk merekam suatu aktivitas siswa dalam proses pembelajaran.

Analisis data aktivitas siswa dalam penelitian ini yaitu analisis kualitatif. Analisis kualitatif dilakukan dengan cara peneliti merefleksi hasil observasi terhadap proses pembelajaran yang dilaksanakan oleh peneliti dan siswa di dalam kelas. Data yang berupa kata-kata dari lembar observasi diolah menjadi kalimatkalimat yang bermakna dan dianalisis secara kualitatif. Metode yang digunakan untuk 
menganalisis data aktivitas siswa yaitu metode analisis dari Miles dan Huberman (Sugiyono, 2017: 246-252). Metode ini terdiri atas tiga komponen yaitu data reduction (Reduksi data), data display (Penyajian data), dan conclusiondrawing/verification

(Penarikan kesimpulan).

Sedangkan data hasil tes pemahaman konsep, dideskripsikan dengan menampung semua jawaban siswa yang beraneka ragam, kemudian jawaban tersebut dibuat tipe-tipe alternatif jawaban siswa. Respon siswa tersebut dideskripsikan dengan cara menghitung persentase jawabannya kedalam masing-masing alternatif jawaban siswa. Selanjutnya, hasil jawaban siswa diperiksa untuk mendapatkan skoring. Skoring ini didasarkan atas kriteria penilaian yang telah dibuat oleh peneliti pada tabel berikut:

Tabel 3.1

Pedoman Penskoran Tes

\begin{tabular}{|c|c|c|}
\hline $\begin{array}{c}\text { Kemampua } \\
\mathbf{n}\end{array}$ & $\begin{array}{c}\text { Skor } \\
\mathbf{s}\end{array}$ & $\begin{array}{c}\text { Keteranga } \\
\mathbf{n}\end{array}$ \\
\hline Pemahaman & 3 & Memberika \\
\hline
\end{tabular}

\begin{tabular}{|l|l|l|}
\hline 2 & n jawaban \\
1 & dengan \\
0 & benar dan \\
& lengkap \\
& Memberika \\
n jawaban \\
dengan \\
benar tapi \\
tidak \\
lengkap \\
Mencoba \\
menjawab \\
tetapi salah \\
Tidak ada \\
jawaban \\
\hline
\end{tabular}

Skor tersebut kemudian diubah ke dalam bentuk nilai persentase. Adapun perhitungannya adalah sebagai berikut:

skor siswa $=\frac{\sum \text { skor butir item }}{\sum \text { skor maksimal }} \times 100$

Nilai persentase siswa merupakan bentuk data interval yang nantinya bisa digunakan untuk menganalisis korelasi antara pemahaman konsep siswa dalam pembelajaran IPA.

Peneliti menjumlahkan nilai yang diperoleh siswa, selanjutnya dibagi dengan jumlah siswa yang 
mengikuti tes sehingga diperoleh nilai rata-rata. Nilai rata-rata ini didapat dengan menggunakan rumus sebagai berikut (Sugiyono 2017: 49):

Dimana:

$$
\mathrm{Me}=\frac{\sum x_{i}}{n}
$$

$$
\begin{aligned}
& \text { Me }=\text { Mean (rata-rata) } \\
& \sum_{\text {jumlah) }}=\text { Epsilon (baca } \\
& x_{i}=\text { Nilai } \times \text { ke i sampai } \\
& \text { ke } \mathrm{n} \\
& \mathrm{N}=\text { Jumlah individu }
\end{aligned}
$$

Dalam penelitian ini terdapat dua kategori ketuntasan belajar yaitu secara individu dan klasikal. Ketuntasan belajar secara individual didapat dari KKM untuk pelajaran IPA yang ditetapkan sekolah yaitu siswa dinyatakan tuntas jika telah mendapatkan nilai sekurang-kurangnya 63 dan di bawah 63 dinyatakan belum tuntas. Setiap siswa dikatakan tuntas belajarnya (ketuntasan individual) jika presentase jawaban benar siswa $\geq 63 \%$. Hal ini sesuai dengan kriteria ketuntasan minimal (KKM) pada pembelajaran IPA. Adapun untuk mengetahui presentase pemahaman konsep siswa dapat dilihat dengan cara perhitungan dibawah ini:

$\begin{aligned} & \text { Presentase Pemahaman } \\ & \text { jumlah skor yang diperoleh siswa }\end{aligned}$
jumlah skor maksimal $100 \%$

Sedangkan ketuntasan belajar secara klasikal yaitu mengukur tingkat keberhasilan ketuntasan belajar siswa menyeluruh. Untuk menghitung persentase ketuntasan belajar klasikal digunakan rumus:

$\mathrm{P}=\frac{\sum \text { jumlah siswa yang mend apat nilai } \geq 63}{\sum \text { siswa mengikuti tes }} \times 100 \%$

Keterangan:

$\mathrm{P}=$ Peresentase ketuntasan

Ketuntasan belajar klasikal dinyatakan berhasil jika persentase siswa yang tuntas belajar atau siswa yang mendapat nilai $\geq 63$ jumlahnya lebih besar dari jumlah siswa seluruhnya. Hasil analisis ini digunakan sebagai bahan refleksi untuk melakukan perencanaan lanjutan dalam pertemuan dan siklus selanjutnya. Hasil analisis juga dijadikan sebagai bahan refleksi dalam memperbaiki rancangan pembelajaran atau bahkan sebagai bahan pertimbangan 
dalam penentuan metode pembelajaran yang tepat.

Untuk mengetahui peningkatan kemampuan pemahaman konsep siswa dianalisis menggunakan $\mathrm{N}-$ Gain Sebagai berikut (Zarkasyi, 2015: 235):

$N-$ Gain $=\frac{\text { Skor Postes }- \text { skor Pretes }}{\text { SMI }- \text { skor Pretes }}$

Keterangan:

$\mathrm{SMI}=$ Skor Maksimum Ideal

C. Hasil Dan Pembahasan

1. Aktivitas siswa dalam pembelajaran IPA dengan menerapkan metode eksperimen dalam pembelajaran IPA

\section{a. Siklus I}

Penelitian tindakan kelas pada siklus I dilaksanakan pada hari Selasa tanggal 1 Agustus 2017. Materi yang dipelajari oleh siswa yaitu perubahan wujud benda mencair dan membeku. Sebelum melakukan tindakan, peneliti terlebih dahulu melaksanakan pretes pada tanggal 28 Juli 2017 Hal ini dilakukan untuk mengetahui sejau mana kemampuan pemahaman konsep yang dimiliki siswa sebelum diberi tindakan. Dengan demikian, peneliti dapat mengetahui seberapa besar hasil dari tindakan yang dilakukan melalui perbandingan antara kemampuan sebelum dan sesudah diterapkannya tindakan. Adapun aktivitas siswa dalam pembelajaran IPA dengan menerapkan metode pembelajaran eksperimen yaitu sebagai berikut:

1) Percobaan awal

Pada tahap percobaan awal guru mendemonstrasikan sebuah percobaan menggunakan alat praktikum yang sudah disediakan sebelumnya yaitu lilin dan korek api seperti pada gambar 4.1 kemudian guru bertanya kepada siswa perubahan apa yang akan terjadi jika seandainya lilin tersebut dipasangkan api di atasnya. Ada beberapa siswa menjawab dengan serentak "menyala" ada juga yang menjawab dengan jawaban yang beda "lilinnya akan ada apinya bu" kemudian ada juga siswa yang hanya diam tidak menjawab. Siswa yang diam tidak menjawab kurang memperhatikan apa yang ditanyakan oleh guru, siswa 
tersebut hanya melihat ke arah alat percobaan yang di demonstrasikan oleh guru.

Tindakan selanjutnya untuk memperbaiki kondisi tersebut, yang dilakukan guru yaitu dengan cara menegaskan pada masingmasing siswa untuk memperhatikan apa yang disampaikan atau ditanyakan oleh guru tidak hanya melihat apa yang di demosntrasikan guru saja sehingga semua siswa bisa lebih fokus dan bisa menjawab apa yang ditanyakan oleh guru.

2) Pengamatan

Pada tahap ini sebenarnya hampir bersamaan dengan percobaan awal, di mana siswa diminta memperhatikan dengan seksama saat

guru mendemonstrasikan percobaan awal, selain memperhatikan demonstrasinya siswa juga harus tahu alat dan bahan apa saja yang di gunakan guru, juga harus tau langkah-langkah atau hal-hal penting saat demonstrasi. Setelah guru meminta siswa untuk menuliskan hal-hal yang perlu di catat baru ada beberapa siswa yang menuliskan alat-alat yang digunakan guru dalam demonstrasi sedangkan masih ada siswa yang tidak menulis hal-hal penting dalam demonstrasi maupun alat dan bahan yang di gunakan, siswa hanya melihat tanpa menulis.

Tindakan selanjutnya untuk memperbaiki kondisi tersebut, yang dilakukan guru yaitu sebelum melakukan percobaan awal guru sudah menegaskan kepada semua siswa agar tidak hanya memperhatikan dengan cara melihat, tetapi mengamati dan mencatat hal-hal penting yang pelu di catat seperti menulis alat dan bahan yang di gunakan atau langkah-langkah demonstrasinya.

3) Hipotesis awal

Pada tahap hipotesis awal guru memberikan sebuah pertanyaan kepada semua siswa "apa yang akan terjadi jika ibu pasangkan lilin dan korek api ini?", pertanyaan tersebut berupa pancingan agar membuat siswa menduga jawabannya sendiri sesuai pemahaman yang dimiliki siswa berdasarkan apa yang diamatinya dari percobaan awal. 
Guru meminta siswa menuliskan hipotesis awal pada buku tugasnya masing-masing di antaranya ada yang menuliskan "menyala dan meleleh, nyala, menyala lilinnya, akan ada apinya, lilin menyala". Kemudian guru memintanya untuk di kumpulkan di meja guru. Akan tetapi ada salah seorang siswa yang tertinggal dalam menulis jawaban dengan alasan bingung untuk menjawabnya dan malah menanyakan pada teman sebangkunya, sehingga ketika temannya mengumpulkan ke meja guru dia masih menulis jawaban.

Tindakan selanjutnya untuk memperbaiki kondisi tersebut, yang dilakukan guru yaitu memberikan pertanyaan disertai penegasan bahwa pertanyaan tersebut harus di jawab secara tertulis dan harus di kumpulkan ke meja guru agar siswa tidak lagi ada yang tertinggal atau bertanya kepada temannya.

4) Verifikasi

Tahap selanjutnya yaitu verifikasi. Tindakan yang dilakukan guru yaitu membagi siswa ke dalam 3 kelompok kecil yang terdiri dari 3-4 orang siswa. Pembagian kelompok ini dilakukan dengan cara berhitung dari 1-3 sesuai dengan tempat duduknya, siswa akan berkelompok dengan siwa yang menyebutkan nomor yang sama misalnya, siswa yang menyebutkan nomor satu akan berkelompok dengan nomor satu lagi, begitupun untuk siswa yang menyebutkan nomor dua dan tiga. Pada saat pembagian kelompok siswa ribut dan suasana kelas berisik sehingga dalam pembentukan kelompok ini memerlukan banyak waktu, sebelumnya juga siswa berlatih untuk berhitung karena ada siswa yang menyebutkan nomor empat sedangkan seharusnya saat nomor tiga sudah disebutkan harus kembali lagi menyebutkan nomor satu hal ini membuat kelas sedikit gaduh.

Tahap selanjutnya tindakan yang dilakukan guru setelah siswa duduk secara berkelompok yaitu meminta kepada tiap-tiap kelompok untuk menentukan ketua kelompok dan kemudian guru memberikan bahan untuk 
percobaan kepada siswa berupa LKS pada masing-masing kelompok untuk di praktekan bersama teman kelompoknya. Setiap kelompok mendapatkan satu set LKS dan satu set alat percobaan sehingga saat guru menjelaskan tujuan dan langkah kerja LKS hanya ketua kelompok yang membaca LKS dan anggota kelompok ada yang mencocokan alat percobaan yang ada dengan yang tertera di LKS sedangkan anggota lainnya hanya diam ada juga yang mulai memainkan alat percobaan (kipas) dengan alasan LKS nya tidak terlihat jelas jika 1 LKS untuk di baca bersama.

Guru hanya membagi satu set LKS pada tiap-tiap kelompok tindakan selanjutnya untuk memperbaiki kondisi tersebut, yang dilakukan guru yaitu guru meberikan dua set LKS ke tiap-tiap kelompok agar semua anggota kelompok bisa ditekankan untuk membaca LKS terlebih dulu, agar tidak ada alasan berebut LKS dengan teman kelompok karena membaca satu LKS bersama tidak terlihat jelas.
LKS pada siklus I terdapat dua soal, soal yang pertama yaitu melakukan percobaan perubahan wujud benda padat ke cair atau mencair dan soal nomor dua yaitu melakukan percobaan benda cair ke padat atau membeku. Pada pengerjaan LKS guru tetap membimbing langkah kerjanya dan membantu ke tiap-tiap kelompok jika ada yang kesulitan dalam percobaan serta guru menyarankan agar siswa tetap dalam keadaan aman dan menjaga kenyamanaan selama percobaan.

Siswa mengikuti langkahlangkah yang ada di LKS dan mengikuti arahan dari guru, siswa cukup antusias dalam percobaan, siswa yang tadinya tidak membaca LKS juga saat percobaan berlangsung mereka cukup aktif karena tertarik dengan percobaan yang mereka lakukan, meskipun ada salah satu kelompok yang anggotanya berebut kipas tangan karena ingin memainkannya.

Tindakan selanjutnya untuk memperbaiki kondisi tersebut, yang dilakukan guru yaitu 
menentukan langsung tugas

masing-masing anggota kelompok, guru tidak hanya menentukan ketua kelompok saja tetapi juga menentukan sekretaris dan moderator atau tugas lain dalam percobaan. Sehingga siswa lebih mempunyai rasa tanggung jawab atas tugas yang diberikan dan tidak terjadi keributan saat melakukan percobaan.

Setelah semua kelompok melakukan percobaan dan berhasil menjawab pertanyaan pada LKS tindakan yang dilakukan oleh guru yaitu melihat hasil diskusi masingmasing kelompok dan meminta masing-masing kelompok untuk menyerahkan hasil diskusi kelompok kemudian perwakilan kelompok menjelaskan jawaban LKS masing-masing kelompok ke depan kelas, pada saat menjelskan siswa hanya membacakan hasil diskusinya saja, sehingga ketika kelompok lain presentasi guru harus membantu menanyakan jawaban kelompok lainya, dan menjelaskan jawaban dari kelompok yang sedang presntasi ada juga kelompok ke tiga tidak ada perwakilan yang mau maju kedepan kelas dengan alasan malu, guru membujuk ketua kelompoknya untuk maju kedepan kelas akhirnya siswa tersebut mau mempresntasikan hasil diskusi kelompoknya.

Setelah semua kelompok mempresntasikan hasil diskusinya, guru meminta masing-masing kelompok untuk mengumpulkan LKS di meja guru. Tindakan selanjutnya untuk memperbaiki kondisi tersebut, yang dilakukan guru yaitu guru meminta siswa menjelaskan cara penyelesaian dari LKS bukan hanya membacakan hasil LKS tapi menjelaskan jawabannya sehingga kelompok yang tidak persentasi dapat memahami maksud dari jawaban masing-masing kelompok tanpa harus di bantu dijelaskan oleh guru dan guru harus memanggil semua anggota kelompok maju kedepan kelas tanpa pewakilan kelompok, agar siswa tidak merasa malu untuk maju sendiri ke depan kelas.

5) Aplikasi konsep 
Pada tahap ke lima yaitu aplikasi konsep. Tindakan guru pada tahap ini memberikan penguatan lagi kepada siswa dan mencontohkan pemanfaatan perubahan wujud benda mencair dam membeku dalam kehidupan sehari-hari, sehingga siswa bisa menyebutkan contoh yang lainnya dan siswa bisa memahami konsep perubahan wujud benda dalam kehidupan sehari-hari. Pada saat guru meminta contoh lainnya banyak siswa yang menyebutkan contoh pemanfaatan perubahan wujud benda mencair dan membeku dalam kehidupan seharihari "kalau beli roti bakar itu hasil dari pencairan mentega juga bu" itu jawaban salah seorang siswa. Kemudian guru meluruskan jawaban siswa saat ada jawaban yang kurang tepat.

6) Evaluasi

Tahap yang terakhir yaitu evaluasi. Pada tahap ini guru memberikan soal postes kepada siswa secara individu. Guru meminta siswa mengisi dengan jawaban yang tepat dan tidak menyontek kepada temannya.
Siswa menerima soal evaluasi dan mengerjakan soal secara individu. Sebelum siswa mengerjakan soal guru meminta siswa untuk mengisi identitas diri terlebih dulu. Siswa mengerjakan soal secara individu dan memakan waktu yang cukup lama untuk beberapa siswa. Setelah semua siswa selesai mengisi soal guru meminta siswa untuk mengumpulkannya di meja guru. Pada tindakan selanjutnya guru harus membatasi waktu saat mengerjakan soal evaluasi.

\section{b. Siklus II}

Pelaksanaan pada siklus II dilaksanakan pada hari Senin tanggal 21 Agustus 2017. Materi yang dipelajari oleh siswa yaitu perubahan wujud benda mengembun, menguap dan menyublim. Sebelum melakukan tindakan, peneliti terlebih dahulu melaksanakan pretes pada tanggal 18 Agustus 2017. Adapun aktivitas siswa dalam pembelajaran IPA dengan menerapkan metode pembelajaran eksperimen yaitu sebagai berikut:

1) Percobaan awal 


\begin{abstract}
Pada tahap percobaan awal sebelum guru melakukan demonstrasi. Guru menegaskan kepada siswa untuk tidak hanya memperhatikan tetapi juga mengamati dan mendengarkan ucapan guru, saat guru bertanya mereka harus siap untuk menjawab.
\end{abstract}

Kemudian

guru

mendemonstrasikan sebuah percobaan menggunakan alat praktikum yang sudah disediakan sebelumnya, kemudian guru bertanya kepada siswa jika air panas dari dalam termos akan dituangkan kedalam gelas kemudian ditutup menggunakan penutup gelas, perubahan apa yang akan terjadi pada bagian bawah penutup gelas. Pada siklus ini semua siswa menjawab pertanyaan guru, ada yang menjawab "nanti tutupnya suka basah kalau sudah lama bu" ada juga yang menjawab "airnya jadi dingin bu" meskipun ada yang kurang tepat tapi siswa tersebut sudah memperhatikan dan mendengarkan guru. Begitupun saat guru mendeomstrasikan percobaan ke dua dan ke tiga siswa tetap fokus dan menjawab pertanyaan-pertanyaan yang di ajukan guru.

2) Pengamatan

Pada siklus ini guru menegaskan kepada siswa untuk mencatat hal-hal penting dari percobaan awal yang didemonstrasikan guru. Semua siswa menulis pada selembar kertas baik itu menulis alat dan bahan maupun langkah-langkah percobaannya. Kemudian guru mendemosntrasikan lagi percobaan awal dan siswa menulis catatan pada selembar kertas setelah mengamati demonstrasi percobaan.

3) Hipotesis awal

Pada tahap hipotesis awal sebelum guru memberikan sebuah pertanyaan kepada semua siswa, guru menegaskan siswa untuk menjawab pertanyaan tersebut secara tertulis dan akan di kumpulkan, pertanyaan tersebut di tulis di satukan dengan catatan pengamatan demonstrasi. Kemudian guru memberikan pertanyaan yang berupa 
pancingan tersebut agar membuat siswa menduga jawabannya sendiri sesuai pemahaman yang dimiliki siswa berdasarkan apa yang diamatinya dari percobaan awal. Semua siswa langsung menuliskan jawaban sesuai pemahaman konsepnya masingmasing begitu guru selesai mengucapkan pertanyaan.

Adapun beberapa jawaban yang di tuliskan siswa pada hipotesis awal yaitu: uap, akan ada air, ada embun, akan ada embun, embung, air menempel. Dan setelah menjawab pertanyaan siswa langsung mengumpulkan ke meja guru tidak ada lagi siswa yang tertinggal menulis hipotesis.

\section{4) Verifikasi}

Pada tahap verifikasi, tindakan yang dilakukan guru yaitu membagi siswa ke dalam tiga kelompok yang terdiri dari 3-4 orang siswa. Pembagian kelompok ini dilakukan dengan cara berhitung dari 1-3 sesuai dengan tempat duduknya, siswa akan berkelompok dengan siwa yang menyebutkan nomor yang sama misalnya, siswa yang menyebutkan nomor satu akan berkelompok dengan nomor satu lagi, begitupun untuk siswa yang menyebutkan nomor dua dan tiga. Pada saat pembagian kelompok siswa tidak lagi ribut untuk berlatih menyebutkan nomor karena sudah memahami bnagaimana cara mereka berhitung sesuai tempat duduknya. Tetapi masih ada siswa yang berisik karena ingin mengetahui siapa yang akan menjadi kelompoknya.

Tahap selanjutnya tindakan yang dilakukan guru setelah siswa duduk secara berkelompok yaitu meminta kepada tiap-tiap kelompok untuk menentukan ketua kelompok, sekretaris dan moderator dan membagi tugas lainnya dan kemudian guru memberikan bahan untuk percobaan kepada siswa berupa LKS pada masing-masing kelompok untuk praktekan bersama anggota kelompoknya. Setiap kelompok mendapatkan dua set LKS agar semua anggota kelompok membaca LKS dan satu set alat percobaan. Pada saat 
siswa membaca tujuan dan langkah pengerjaan LKS ada siswa yang membaca dengan nyaring ada juga yang hanya di dalam hati.

LKS pada siklus II terdapat tiga soal, soal yang pertama yaitu melakukan percobaan perubahan wujud benda uap ke cair atau mengembun, soal nomor dua yaitu melakukan percobaan benda cair ke gas atau menguap dan soal nomor tiga melakukan percobaan perubahan wujud benda padat ke gas atau menyublim. Pada pengerjaan LKS guru tetap membimbing langkah kerjanya dan membantu ke tiap-tiap kelompok jika ada yang kesulitan dalam percobaan serta guru menyarankan agar siswa tetap dalam keadaan aman dan menjaga kenyamanaan selama percobaan. Guru juga menegaskan agar siswa ingat dengan tugasnya masing-masing dan tetap bekerja sama. Siswa Nampak jelas bekerja sama. Terdengar pula pembicaaraan salah seorang siswa bersama teman kelompoknya saat dia membuka tutp gelas "ada airnya" kemudian teman nya menjawab "ini itu embun" dan dua teman lainnya meluruskan "iya ini namanya embun". Siswa mengikuti langkah-langkah yang ada di LKS dan mengikuti arahan dari guru, siswa cukup antusias dalam percobaan dan bertanggung jawab pada tugasnya masing-masing.

Setelah semua kelompok melakukan percobaan dan berhasil menjawab pertanyaan pada LKS tindakan yang dilakukan oleh guru yaitu melihat hasil diskusi masingmasing kelompok dan meminta masing-masing kelompok untuk menyerahkan hasil diskusi kelompok kemudian setiap kelompok yang ditunjuk maju kedepan kelas semua anggotanya harus ikut maju kedepan kelas untuk melaporkan hasil percobaannya. Pada saat presentasi siswa tidak lagi hanya membacakan hasil diskusinya tetapi menjelaskannya karena di bantu oleh teman kelompoknya. Sehingga guru hanya mendampingi dan meluruskan 
apabila ada jawaban yang salah atau kurang tepat. Setelah semua kelompok mempresntasikan hasil diskusinya, guru meminta masingmasing kelompok untuk mengumpulkan LKS di meja guru.

5) Aplikasi konsep

Pada tahap ke lima yaitu aplikasi konsep. Tindakan guru pada tahap ini memberikan penguatan lagi kepada siswa dan mencontohkan pemanfaatan perubahan wujud benda mengembun, menguap dan menyublim dalam kehidupan sehari-hari, sehingga siswa bisa menyebutkan contoh yang lainnya dan siswa bisa memahami konsep perubahan wujud benda dalam kehidupan sehari-hari. Pada saat guru meminta contoh lainnya banyak siswa yang menyebutkan contoh pemanfaatan perubahan wujud benda mengembun, menguap dan menyublim dalam kehidupan sehari-hari, seperti siswa bernama Riko menjawab "baju yang harum hasil dari proses menguap minyak wangi di baju ya bu?" ada juga yang menjawab "di mobil bisa harum hasil dari proses menyumblim nya pewangi mobil bu". Kemudian guru meluruskamn jawaban siswa saat ada jawaban yang kurang tepat.

6) Evaluasi

Tahap evaluasi di siklus II sebelum guru membagikan soal postes kepada siswa guru meberikan batasan waktu dalam pengerjaan soal. Guru meminta siswa mengisi dengan jawaban yang tepat dan tidak menyontek kepada temannya. Siswa menerima soal evaluasi dan mengerjakan soal secara individu. Sebelum siswa mengerjakan soal guru meminta siswa untuk mengisi identitas diri terlebih dulu. Siswa mengerjakan soal secara individu dan berhasil mengsisi soal dengan batas waktu yang di tentukan guru. Setelah semua siswa selesai mengisi soal guru meminta siswa untuk mengumpulkannya di meja guru.

Penerapan metode eksperimen memberikan kesempatan kepada siswa baik perorangan atau kelompok, untuk dilatih melakukan suatu percobaan atau eksperimen Adapun langkah-langkah 
penerapan metode eksperimen yaitu sebagai berikut: percobaan awal, pada tahap ini diawali dengan percobaan yang didemosntrasikan oleh guru, selanjutnya siswa memperhatikan apa yang di sampaikan oleh guru dalam percobaan awal.

Pengamatan, pada tahap ini siswa melanjutkan pengamatan dari demonstrasi percobaan awal, siswa mencatat hal-hal yang menurutnya penting dan mencatat alat dan bahan yang digunakan dalam percobaan. (3) Hipotesis awal, setelah siswa melakukan pengamatan, guru akan memberikan pertanyaan sebagai pancingan agar siswa mampu membuat dugaan atau membuat hipotesis dari pertanyaan yang diberikan guru sesuai dengan percobaan awal. (4) Verifikasi, pada tahap ini merupakan kegiatan untuk membuktikan kebenaran dari dugaan awal yang telah dirumuskan dan dilakukan melalui kerja kelompok, siswa di harapkan merumuskan hasil percobaan dan membuat kesimpulan, selanjutnya dapat dilaporkan hasilnya.
Guru

mengorganisasikan siswa untuk melakukan percobaan agar siswa mampu mencari dan menemukan sendiri berbagai jawaban atau persoalan persoalan yang dihadapinya dengan maengadakan percobaan sendiri, pada tahap ini siswa di bentuk kedalam kelompok belajar untuk melakukan percobaan, siswa dibagi tugas masing-masing dalam berkelompok dan diharapkan agar setiap siswa aktif dalam melaksanakan percobaan dan memiliki rasa tanggung jawab dengan tugas yang diberikan. Percobaan tersebut bertujuan untuk membuktikan dugaan awal dan membangun pemahaman konsep siswa, sejalan dengan Schoenher (Heriawan, 2012: 86):

Metode eksperimen adalah metode yang sesuai untuk pembelajaran sains, karena metode eksperimen mampu memberikan kondisi belajar yang dapat mengembangkan kemampuan berpikir dan kreatifitas secara optimal. Siswa di beri kesempatan untuk menyusun sendiri 
konsep-konsep dalam struktur kognitifnya, selanjutnya dapat diaplikasikan dalam

kehidupannya.

Hal tersebut di dukung juga oleh teori belajar penemuan yang dikemukakan Bruner (Dahar, 2011: 79) "belajar penemuan sesuai dengan pencarian pengetahuan secara aktif oleh manusia dan dengan sendirinya memberikan hasil yang paling baik. Berusaha sendiri untuk mencari pemecahan masalah serta pengetahuan yang menyertainya, menghasilkan pengetahuan yang benar-benar bermakna". Kemudian pada tahap ini, masing-masing kelompok untuk mendiskusikan hasil percobaannya dengan kelompok lain, diharapkan setiap kelompok memiliki pemahaman dari apa yang didapatkan bersama kelompoknya sehingga dapat menumbuhkan pemahaman konsep siswa karena meurut Jufri (2013: 61):

$\begin{array}{lr}\text { Pemahaman } & \text { diekspresikan } \\ \text { dalam bentuk } & \text { kemampuan } \\ \text { memahami } & \text { informasi, } \\ \text { memanfaatkan } & \text { dan } \\ \text { mengekstrapolasi } & \text { pengetahuan }\end{array}$

$\begin{array}{lr}\text { dalam konteks } & \begin{array}{r}\text { baru, } \\ \text { makna, } \\ \text { menjelaskan } \\ \text { menginterpretasi }\end{array} \\ \text { memprediksi } & \text { fakta, }\end{array}$
mengekstrapolasi pengetahuan tersebut untuk dimanfaatkan dalam situasi lain.

Langkah ke (5) Aplikasi konsep, pada tahap ini setelah siswa merumuskan dan menemukan konsep, hasilnya di aplikasikan dalam kehidupannya. Kegiatan ini merupakan pemantapan konsep yang telah dipelajari. Guru memberikan penguatan kepada siswa tentang pemanfaatan perubahan wujud benda dalam kehidupan seharihari. (6) Evaluasi, tahap ini merupakan tahap terakhir setelah selesai suatu konsep guru memberikan evaluasi berupa soal postes kepada siswa di akhir pembelajaran tujuannya untuk mengetahui sejauhmana pemhaman konsep siswa pada materi perubahan wujud benda yang telah dipelajarinya.

\section{Peningkatan pemahaman} konsep IPA dengan 
menerapkan

metode

eksperimen.

Berdasarkan deskripsi hasil data yang telah diolah ditemukan perkembangan yang positif mengenai pemahaman konsep siswa kelas IV dalam pembelajaran IPA. Siklus I, perolehan rata-rata pemahaman konsep siswa sebesar 76,45 dengan jumlah siswa yang tuntas dalam belajar (Skor $\geq \mathrm{KKM}$ ) sebanyak 10 orang siswa atau 90\%. Kemudian, siklus II perolehan rata-rata pemahaman konsep siswa sebesar 88,18 dengan jumlah siswa yang tuntas belajar sebanyak 11 siswa (100\%). Data tersebut digambarkan pada diagram 4.1 di bawah ini:

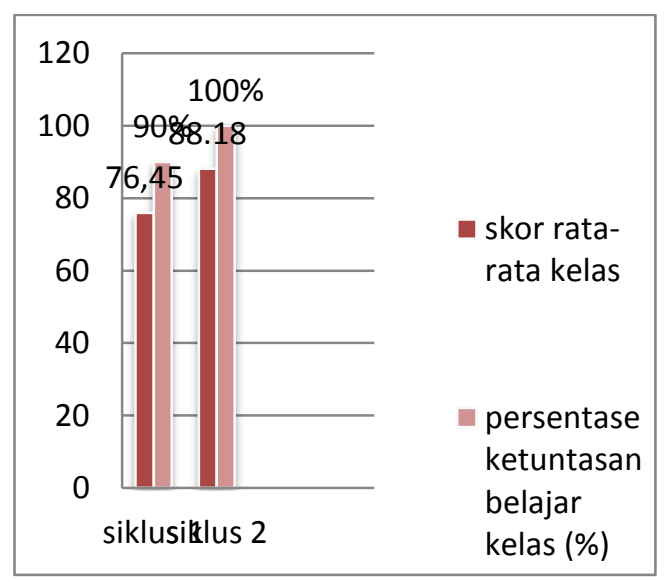

Diagram 4.1

Rata-rata Kelas dan Ketuntasan
Belajar Kemampuan Pemahaman Konsep Siswa

Selain kemampuan pemahaman konsep siswa yang mengalami perkembangan yang positif, peningkatan kemampuan pemahaman konsep siswa pun mengalami perkembangan yang positif. Hal tersebut dapat dilihat dari $\mathrm{N}$-gain siklus I sebesar 0,50 siklus dan siklus II sebesar 0,70. Adapun data perkembangan peningkatan pemahaman konsep siswa kelas IV dapat dilihat pada Diagram 4.2 di bawah ini:

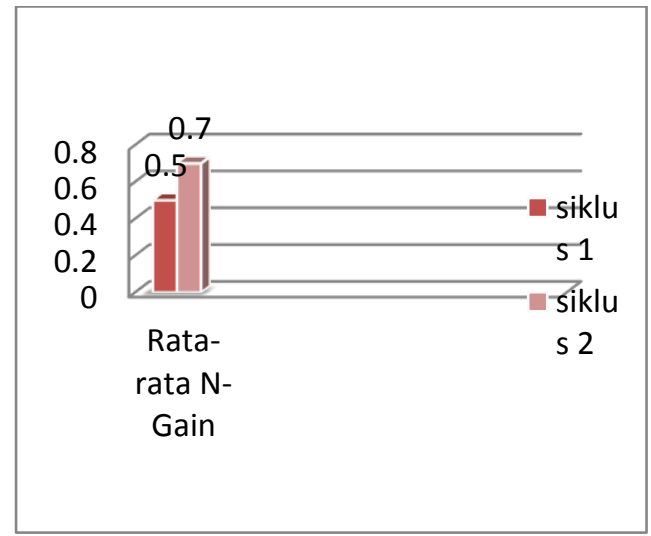

Diagram 4.2

Perkembangan Rata-rata N-Gain

Penerapan metode pembelajaran eksperimen secara umum meningkatkan pemahaman konsep siswa kelas IV. Hal demikian didukung oleh teori Piaget (Suyono, 2016: 86) bahwa belajar akan lebih berhasil jika di 
sesuaikan dengan tahap perkembangan kognitif siswa. Siswa hendaknya di beri kesempatan untuk melakukan eksperimen dengan objek fisik yang ditunjang oleh interaksi dengan teman sebaya dan dibantu oleh pertanyaan tilikan dari guru.

Guru hendaknya memberikan rangsangan kepada peserta didik agar mau berinteraksi dengan lingkungan secara aktif, mencari, mengamati dan menemukan, memungut berbagai hal dari lingkungan. Pembangunan kemampuan kognitif harus melalui pengalaman atau tindakan yang termotivasi dengan sendirinya terhadap lingkungan, jadi pembelajaran harus bersifat aktif karena metode eksperimen adalah sebuah metode pembelajaran aktif dan partisipatif. Sebagaimana kelebihan metode eksperimen yang di kemukakan oleh Roestiyah (2012: 82):

Mereka lebih aktif berpikir dan berbuat, hal mana itu sangat di kehendaki oleh kegiatan mengajar belajar yang modern dimana siswa lebih banyak aktif belajar sendiri dengan bimbingan guru dan juga siswa dapat melaksanakan proses eksperimen disamping memperoleh ilmu pengetahuan juga menemukan pengalaman praktis serta keterampilan dalam menggunakan alat-alat percobaan.

\section{KESIMPULAN}

1. Aktivitas siswa dalam pembelajaran IPA materi perubahan wujud benda dengan menggunakan metode eksperimen yaitu: pada tahap pertama siswa memperhatikan percobaan awal yang di lakukan oleh guru yang dibuktikan dengan menjawab pertanyaan yang diajukan guru seputar percobaan. Kemudian di tahap pengamatan semua siswa mencatat hal-hal yang terjadi saat mengamati percobaan yang dilakukan guru. Tahap yang ke tiga siswa membuat hipotesis sesuai pemhaman konsepnya 
berdasarkan pengamatan dari percobaan yang dilakukan guru. Selanjutnya di tahap verifikasi siswa melakukan percobaan yang mengacu pada LKS dengan cara berkelompok, siswa membagi tugas masingmasing pada setiap anggota kelompok seperti tugas sebagai ketua kelompok, sekretaris, moderator dan tugas lainnya dalam percobaan. Setelah siswa menyelesaikan percobaanya setiap kelompok berdiskusi atau mempresentasikan hasil pengamatan kelompoknya di depan kelas. Tahap yang kelima yaitu aplikasi konsep, siswa mampu memberikan contoh pemnafaatan perubahan wujud benda dalam kehidupan sehari-hari.

2. Peningkatan kemampuan pemhaman konsep IPA kelas IV SD Negeri Wirukencana dengan menggunakan metode eksperimen pada materi perubahan wujud benda mengalami perkembangan yang positif. Peningkatan ini dapat dilihat dari N-Gain siklus I sebesar 0,50 dan siklus II 0,70. Rata-rata kemampuan pemahaman konsep siswa kelas IV, siklus I yaitu 76,45 dan siklus II mendapatkan nilai rata-rata 88,18 dan ketuntasan belajar kelas siklus I yaitu $90 \%$, dan siklus II mencapai 100\%.

\section{DAFTAR PUSTAKA}

Anderson,L. W. dan D. R. Krathwohl (2015). Kerangka Landasan Untuk. Pembelajaran, Pengajaran, dan Asesmen Revisi Taksonomi Pendidikan Bloom. Terjemahan : Agung Prihantoro.Yogyakarta: Pustaka Belajar

Arikunto, S. (2013). Penelitian Tindakan Kelas. Jakarta: PT. Bumi Aksara.

Dahar, R.W. (2011). Teori-Teori Belajar dan Pembelajaran. Jakarta : Erlangga.

Heriawan, A., dkk. (2012). Metodologi Pembelajaran Kajian Teoritis Praktis Model, Pendekatan, Strategi, Metode, dan Teknik Pembelajaran.Banten: LP3G

Jufri, Wahab. (2013). Belajar dan Pembelajaran Sains. Bandung: Pustaka Reka Cipta.

Rafika. (2015). Upaya Meningkatkan Pemahaman Konsep Gaya Dengan Menggunakan Metode Eksperimen Siswa Kelas IV SDN I Siwalempu. Jurnal Kreatif TadulakoOnline Vol 4 No.2 HIm. 10-24. 
Ratumanan, Tanwey, Gerson, Drs., M.Pd. (2002). Belajar dan Pembelajaran. Surabaya. Unesa University Press

Roestiyah. (2012). Strategi Belajar Mengajar. Jakarta: Rineka Cipta
Sugiyono. (2017). Metode Penelitian Kuantitatif, Kualitatif dan R\&D. Bandung: PT Alfabet.

Suyono, (2016). Belajar dan Pembelajaran. Bandung: PT REMAJA ROSDAKARYA. 